\title{
Prevalence of dizziness and associated factors in institutionalized elderly persons
}

\author{
Prevalência de tontura e fatores associados em pessoas idosas \\ institucionalizadas
}

Lidiane Maria de Brito Macedo Ferreira, Karyna Myrelly Oliveira Bezerra de Figueiredo Ribeiro, Kênio Costa de Lima

\footnotetext{
Study performed at Department of Odontology and Department of Physiotherapy, Federal University of Rio Grande do Norte (UFRN), Brazil.

Financial support: none.

Conflict of interest: None.

Correspondence address: Department of Odontology, Federal University of Rio Grande do Norte, at Ave. Salgado Filho 1787, Natal, RN, Brazil, E-mail: lidianembm@yahoo.com.br

Submitted: October 10, 2015. Accepted, after review: December 12, 2015.
}

\begin{abstract}
Dizziness is a common symptom among the elderly, and is more prevalent among institutionalized elderly persons, due to their immobility and fragility. Objective: The aim of the present study was to ascertain the prevalence of dizziness and associated factors in institutionalized elderly persons. Methods: A cross-sectional study was performed in 12 Nursing Homes in Natal, Brazil. Elderly persons who possessed a cognitive level that allowed them to answer questions consciously, and were able to walk, were selected, resulting in a total sample of 115 individuals. They were asked whether they had experienced dizziness in the past year. Variables relating to the characteristics of the nursing homes, the dizziness, the life habits and the health of the elderly were evaluated. The Chi-square test for a significance level of $5 \%$ was used for statistical analysis, and the prevalence ratio (PR) calculated. For multivariate analysis, logistic regression was performed. Results: The prevalence of dizziness was $44.34 \%$. Most elderly persons were female, long-lived, resided in non-profit facilities where they had lived for less than four years, had less than three diseases, used between 0 and 5 types of medication, did not smoke or drink, did not partake in physical inactivity, had rapid, imbalance type dizziness without neurovegetative symptoms and/or associated neurotological symptoms. Dizziness was associated with a large number of illnesses, the presence of cardiovascular disease, arterial hypertension, osteoarthritis and the use of gastro-protective medication. Conclusion: There was
\end{abstract}


a high prevalence of dizziness among institutionalized elderly persons and was associated with cronic disease.

Key words: Aged. Dizziness. Nursing Homes.

\section{RESUMO}

A tontura é um sintoma comum entre os idosos e é mais prevalente entre os institucionalizados, devido à sua imobilidade e fragilidade. Objetivo: O objetivo do presente estudo foi aferir a prevalência de tontura e os fatores associados em idosos institucionalizados. Métodos: Estudo transversal, realizado em 12 instituições de longa permanência para idosos em Natal, Brasil. Foram selecionados idosos com nível cognitivo suficiente para responder a perguntas de forma consciente e capazes de deambular, totalizando 115 indivíduos. Estes foram questionados sobre a presença de tontura no último ano. Foram avaliadas variáveis relativas às características das instituições, da tontura, dos hábitos de vida e da saúde dos idosos. Para a análise estatística, utilizou-se o teste do Quiquadrado para um nível de significância de 5\% e cálculo da Razão de Prevalência $(\mathrm{RP})$, e para análise múltipla, foi realizada a regressão logística. Resultados: $A$ prevalência de tontura foi de 44,34\%. A maioria dos idosos era do sexo feminino, longevos, residiam em instituições sem fins lucrativos, com menos de 4 anos de institucionalização, possuíam menos de 3 doenças, usavam entre 0 e 5 medicamentos, não eram tabagistas nem etilistas, não praticavam atividade física, possuíam tontura tipo desequilíbrio, rápida, sem sintomas neurovegetativos e sem sintomas otoneurológicos associados. A tontura foi associada com um grande número de doenças, a presença de doença cardiovascular, hipertensão arterial, a osteoartrite e a utilização de medicação gastro-protectora. Conclusão: Houve uma alta prevalência de tontura em idosos institucionalizados e esta foi associada com doença crônica.

Descritores: Idoso. Tontura. Instituição de longa permanência para idosos.

\section{INTRODUCTION}

The aging of the Brazilian population in recent years has created concerns over potential consequences for public health, such as spending on preventive measures and treatment of chronic degenerative diseases.

Polymedicated elderly persons with a combination of various diseases, who often require multidisciplinary treatment and adjustments to the day-to-day 
routines, not only of the elderly person but also of his or her family, are common. One major question to be discussed is that more and more elderly persons live alone, live only with a caregiver, or reside in Nursing Homes (NH). Such institutions can create social isolation among the elderly, who often feel deprived of their previous activities and lose their independence and functionality. Currently, the majority of elderly persons living in Nursing Homes sare affected by incapacitating illness, dementia or terminal illness ${ }^{1}$.

The role of the family in caring for the elderly person continues to diminish, which represents a failure in care, and results in complications related to preexisting diseases. These can lead to immobility, frailty and falls, the last generally related to balance disorders (which represent $85 \%$ of falls among elderly persons). The main symptom of this imbalance is dizziness ${ }^{2}$.

Dizziness is the feeling of loss of body balance, defined as the erroneous perception, illusion or hallucination of motion, imbalance, visual distortion and sense of spatial disorientation, rotary type or otherwise ${ }^{3}$. It is a very common symptom among the elderly, with literature indicating a prevalence of between $19 \%$ and $38 \%{ }^{4-6}$. Brazilian study reveal higher percentages of $74 \%$ among elderly persons living in the community ${ }^{7}$, while this percentage rises to $81-91 \%$ among elderly persons attending geriatric outpatient $\operatorname{clinics}^{3,8}$.

A multifactorial syndrome is involved in the genesis of dizziness among most elderly persons, caused by disorders in various systems (sensory, neurological, cardiovascular, vestibular, and others). Such a syndrome involves disorders associated with aging, pathologies connected with dizziness (cardiovascular, peripheral vestibular or central, metabolic, visual, and osteoarticular among others) and situations related to the lifestyle of the patient (medication use, smoking, alcohol consumption, physical activity) ${ }^{9}$.

In seeking to identify these causes, studies have found that associated diseases and the use of medication are the main factors related to dizziness, although these do not generally act in isolation. A total of $51 \%$ of elderly persons had more than one etiology for change in balance ${ }^{10}$. Institutionalized elderly persons, who are more affected by illnesses than elderly persons living in the community, possibly suffer more from dizziness. 
The aim of the present study was to assess the prevalence of dizziness in institutionalized elderly persons in Natal, Brazil, and factors associated with the symptom.

\section{METHODS}

The study complied with the criteria and requirements established by Resolution No. 466/12 of the National Health Council (CNS) and followed the recommendations of the Federal University of Rio Grande do Norte (UFRN) Research Ethics Committee (CEP), and was approved under protocol number $309 / 2012$. All the elderly persons voluntarily agreed to participate and signed Letters of Free and Informed Consent.

A population-based cross-sectional study was performed of elderly residents of both private and non-profit $\mathrm{NH}$, regulated by the Health Surveillance Department, in the city of Natal, Brazil. The municipality has $12 \mathrm{NH}$, six of which are private and six of which are nonprofit, which resulted in a total of 386 elderly persons.

Included in the study were elderly persons who were present in the $\mathrm{NH}$ at the time of examination and who did not meet any of the following exclusion criteria: serious problems with memory, attention, temporal and spatial orientation and communication. The identification of such elderly persons was undertaken through conversation with caregivers, who identified which elderly persons were able to respond to the questionnaire and undergo physical tests. The permanent or temporary inability to walk was considered to be a further exclusion criteria, with the use of a cane or walker, but not a wheelchair, being allowed. A total of 123 elderly persons were excluded from the study. Of these, eight refused to participate, resulting in a total of 115 persons.

The research tool used was a questionnaire aimed at the elderly persons themselves, together with an analysis of medical records. This collection form was completed with general information about the facility, the health of the patient and his or her general life habits. The initial question, which aimed to identify prevalence, was: Have you experienced dizziness in the last 12 months? 
After data was collected, descriptive analysis was performed to identify elderly persons with dizziness, as well as bivariate analysis using the Chi-squared or Fisher's Exact tests for a significance level of $5 \%$, in addition to calculating the Prevalence Ratio (PR). In multivariate analysis, was used logistic regression to calculate Odds Ratio adjusted.

\section{RESULTS}

Of the 115 elderly persons who took part in the survey, 51 reported having suffered from dizziness in the previous 12 months, resulting in a prevalence of $44.34 \%$.

The elderly patients with dizziness were mostly female, long-lived, resided in non-profit facilities and had been institutionalized for less than four years, had less than three diseases, used five or fewer drugs, did not smoke or consume alcohol, did not exercise, had rapid, imbalance type dizziness without neurovegetative symptoms and associated neurotological symptoms (Table 1).

Table 1 - Profile of elderly persons with dizziness and characteristics of dizziness among such persons in nursing homes

\begin{tabular}{lcc}
\hline & $\mathbf{n}$ & $\%$ \\
\hline Gender & 18 & 35.3 \\
$\quad$ Male & 33 & 64.7 \\
$\quad$ Female & 06 & \\
\hline Age & 15 & 11.7 \\
64 to 70 years & 26 & 29.4 \\
71 to 80 years & 04 & 50.9 \\
81 to 90 years & & 07.8 \\
$\quad$ More than 90 years & 37 & 72.5 \\
\hline Type of NH & 14 & 27.5 \\
$\quad$ Non-profit & 16 & 31.4 \\
$\quad$ Private & 35 & 68.6 \\
\hline Length of time spent in facility & & \\
4 years or more & 24 & 47.1 \\
3 years or less & 27 & 52.9 \\
\hline Number of illnesses & & \\
3 or more & 25 & 49 \\
2 or less & 26 & 51 \\
\hline Number of medications taken & & \\
6 or more & & \\
5 or less & & \\
\hline
\end{tabular}




\begin{tabular}{|c|c|c|}
\hline \multicolumn{3}{|l|}{ Alcohol Consumption } \\
\hline Yes & 04 & 07.8 \\
\hline No & 47 & 92.2 \\
\hline \multicolumn{3}{|l|}{ Smoke } \\
\hline Yes & 07 & 13.7 \\
\hline No & 44 & 86.3 \\
\hline \multicolumn{3}{|l|}{ Sedentary lifestyle } \\
\hline Yes & 35 & 68.6 \\
\hline No & 16 & 31.4 \\
\hline \multicolumn{3}{|l|}{ Type of dizziness } \\
\hline Vertigo & 13 & 25.5 \\
\hline Imbalance & 18 & 35.3 \\
\hline Floating sensation & 08 & 15.7 \\
\hline Floating sensation + Presyncope & 02 & 03.9 \\
\hline Floating sensation + Vertigo & 02 & 03.9 \\
\hline Did not respond & 08 & 15.7 \\
\hline \multicolumn{3}{|l|}{ Duration of dizziness } \\
\hline Seconds & 19 & 37.3 \\
\hline Minutes & 18 & 35.3 \\
\hline Hours & 04 & 07.8 \\
\hline Days & 02 & 03.9 \\
\hline Did not respond & 08 & 15.7 \\
\hline \multicolumn{3}{|l|}{ Hearing loss } \\
\hline Yes & 17 & 33.3 \\
\hline No & 26 & 51.0 \\
\hline Did not respond & 08 & 15.7 \\
\hline \multicolumn{3}{|l|}{ Presence of tinnitus } \\
\hline Yes & 21 & 41.2 \\
\hline No & 22 & 43.1 \\
\hline Did not respond & 08 & 15.7 \\
\hline \multicolumn{3}{|l|}{ Presence of aural fullness } \\
\hline Yes & 15 & 29.4 \\
\hline No & 28 & 54.9 \\
\hline Did not respond & 08 & 15.7 \\
\hline \multicolumn{3}{|c|}{ Presence of neurovegetative symptoms } \\
\hline No & 11 & 21.6 \\
\hline Did not respond & 32 & 62.7 \\
\hline & 08 & 15.7 \\
\hline
\end{tabular}

In relation to factors associated with dizziness, it was observed that dizziness was more prevalent among elderly persons with cardiovascular disease, hypertension and osteoarthritis than among persons without such diseases, as well as among those with a combination of various diseases and use of gastric protectors. When performed the multivariate analysis, only cardiovascular disease was associated with dizziness, adjusted for 
hypertension, dementia, drugs for osteo-articular diseases and gastric protectors drugs (Table 2).

Table 2 - Absolute values and percentages, statistical significance, rp and confidence intervals and adjusted or with $\mathrm{p}$ value for the variables that entered the multivariate analysis model.

\begin{tabular}{|c|c|c|c|c|c|c|}
\hline \multirow{2}{*}{ Variable } & \multicolumn{2}{|c|}{ Dizziness } & \multirow[b]{2}{*}{$p$} & \multirow[b]{2}{*}{ PR (Cl) } & \multirow[b]{2}{*}{$p$} & \multirow{2}{*}{$\begin{array}{l}\text { PR adjusted } \\
\text { (IC) }\end{array}$} \\
\hline & $\begin{array}{l}\text { Yes } \\
\mathrm{n}(\%)\end{array}$ & $\begin{array}{l}\text { No } \\
\mathrm{n}(\%)\end{array}$ & & & & \\
\hline $\begin{array}{l}\text { Dementia Yes } \\
\text { Dementia No }\end{array}$ & $\begin{array}{l}13(33.3) \\
38(50.0)\end{array}$ & $\begin{array}{l}26(66.7) \\
38(50.0)\end{array}$ & 0.132 & $\begin{array}{c}0.667 \\
(0.405-1.096)\end{array}$ & 0.109 & $\begin{array}{c}0.482 \\
(0.198-1.178)\end{array}$ \\
\hline $\begin{array}{l}\text { Parkinson's DiseaseYes } \\
\text { Parkinson's Disease No }\end{array}$ & $\begin{array}{l}05(83.3) \\
45(41.7)\end{array}$ & $\begin{array}{l}01(16.7) \\
63(58.3)\end{array}$ & 0.114 & $\begin{array}{c}2.000 \\
(1.312-3.049)\end{array}$ & - & - \\
\hline $\begin{array}{l}\text { Migraines Yes } \\
\text { Migraines No }\end{array}$ & $\begin{array}{l}04(80.0) \\
47(42.7)\end{array}$ & $\begin{array}{l}01(20.0) \\
63(57.3)\end{array}$ & 0.238 & $\begin{array}{c}1.872 \\
(1.148-3.052)\end{array}$ & - & - \\
\hline $\begin{array}{l}\text { CVD Yes } \\
\text { CVD No }\end{array}$ & $\begin{array}{l}17(70.8) \\
34(37.4)\end{array}$ & $\begin{array}{l}07(29.2) \\
57(62.6)\end{array}$ & $0.007^{\star}$ & $\begin{array}{c}1.896 \\
(1.310-2.744)\end{array}$ & $0.030^{* *}$ & $\begin{array}{c}3.209 \\
(1.117-9.218)\end{array}$ \\
\hline $\begin{array}{l}\text { Osteoarthritis Yes } \\
\text { Osteoarthritis No }\end{array}$ & $\begin{array}{c}8(100) \\
43(40.2)\end{array}$ & $\begin{array}{c}0(0) \\
64(59.8)\end{array}$ & $0.001^{*}$ & & - & - \\
\hline $\begin{array}{l}\text { Number of illnesses } \\
3 \text { or more } \\
2 \text { or less }\end{array}$ & $\begin{array}{l}24(60) \\
27(36)\end{array}$ & $\begin{array}{l}16(40) \\
48(60)\end{array}$ & $0.023^{*}$ & $\begin{array}{c}1.667 \\
(1.124-2.471)\end{array}$ & - & - \\
\hline $\begin{array}{l}\text { Use of medication proton pump inhibitor } \\
\text { Yes } \\
\text { No }\end{array}$ & $\begin{array}{l}20(64,5 \%) \\
31(36,9 \%)\end{array}$ & $\begin{array}{l}11(35,5 \%) \\
53(63,1 \%)\end{array}$ & $0.008^{*}$ & $\begin{array}{c}1.748 \\
(1.192-2.563)\end{array}$ & 0.109 & $\begin{array}{c}2.144 \\
(0.843-5.454)\end{array}$ \\
\hline
\end{tabular}




\section{DISCUSSION}

Dizziness is a very common symptom among the elderly population and may represent a number of health problems in various organs and systems. It is important not only because of the physical discomfort it causes, but most importantly, because of the consequences that it may generate, such as falls and related complications. Fabricio et $\mathrm{al}^{11}$ found that dizziness was the most frequent physical cause of falls in institutionalized elderly persons.

The prevalence of dizziness among elderly persons described in international literature varies considerably, with a mean of approximately $30 \%$ in population-based studies ${ }^{4-6}$. In an epidemiological study, Moraes et al ${ }^{8}$ found a slightly higher prevalence of dizziness, $45 \%$, in non-institutionalized persons. In the present study, the prevalence rate was $44.34 \%$, a value slightly higher than that reported in international literature, but consistent with data for Brazil. It is important to remember, however, that this is a population of institutionalized elderly persons, who, as described above, are more predisposed to risk factors that generate dizziness. Additionally, the fact that the majority were aged between 81 and 90 years corroborated studies that found that the prevalence of dizziness increases with age, reaching $50 \%$ in persons older than 85 years ${ }^{9,12}$. Several studies have confirmed the trend of dizziness among older elderly persons, possibly because elderly people are living longer today, and therefore present this symptom more frequently $8,10,13,14$.

The most common type of dizziness in the present study was imbalance, possibly due to the comorbidities of the elderly persons in the sample, and the next most common was vertigo. Some studies, however, found pre-syncope to be the most common type of dizziness among the elderly ${ }^{14,15}$. In general, dizziness is triggered by several factors in elderly patients and therefore classification, as a rule, is imprecise, with overlapping of types. Associations with vascular, metabolic and osteoarticular diseases confirm that imbalance may indeed have a multifactorial origin.

Otoneurological symptoms are not always present in bouts of dizziness, as they depend on the direct or indirect involvement of the vestibulocochlear system. In this study such symptoms were reported by around one-third of the 
elderly persons $(21.6 \%$ had nausea, $41.2 \%$ tinnitus, $29.4 \%$ aural fullness and $33.3 \%$ self-reported hearing loss). Some studies have described the presence of these symptoms associated with dizziness, but there is little agreement among prevalence rates (nausea: 27 to 40\%, tinnitus 10 to $73 \%$, hearing loss 6 to $35 \%)^{8,14}$.

With regard to factors related to the nursing homes, it was investigated whether the type of institution, in terms of financing (private or non-profit) influenced the onset of dizziness in any way, but the study data revealed no association. Likewise, the amount of time spent living in the facility did not have a significant effect on the onset of symptoms. What is known is that institutionalization weakens and undermines the health of older people, and that the reduction in their mobility is one of the most frequent causes of disability. In such a scenario changes in balance occur ${ }^{16}$. However, in the present study no such relationship was observed.

The habits of elderly persons were also evaluated as a potential influence on the occurrence of dizziness, but the present study did not find a significant association due to the low prevalence of physical activity, smoking and alcohol abuse in the sample.

Among elderly persons, physiological changes that result from aging cannot be dissociated from diseases that arise over the years, and this union of factors leads to the emergence of symptoms. Dizziness can be the result of various diseases acting on a body already weakened by natural wear, causing injuries as maintaining body balance becomes more difficult. The diseases most commonly described in literature as forming part of the genesis of dizziness are hypertension, cardiovascular disease, diabetes and dyslipidemia, confirming the influence of microcirculatory and metabolic changes in the cerebral and vestibular blood flow. Bittar et $\mathrm{al}^{13}$ found that $32.3 \%$ of patients with dizziness had undergone vascular changes, $29.9 \%$ had experienced dyslipidemia and $13.8 \%$ had suffered changes to their sugar metabolism.

In the search for the association between dizziness and diseases common to senescence, data from the present study showed that elderly people with a high number of comorbidities were $66 \%$ more likely to experience dizziness that an elderly person with less than three related diseases, 
strengthening the theory of multiple causality in the occurrence of dizziness. Studies have found that the greater the number of associated diseases, the greater the risk of dizziness, especially if the number of diseases is greater than three ${ }^{17,18}$. There are proven associations between dizziness and hypertension, where the risk of dizziness is 1.85 times greater, and depression, where the risk is 2.17 times greater ${ }^{19}$.

Dizziness was $89 \%$ more prevalent among elderly persons with cardiovascular disease, and $93 \%$ more prevalent in elderly persons with hypertension, revealing an intimate association between circulatory disorders and the presence of dizziness. The association of cardiovascular disease with dizziness was confirmed by multiple analysis, the statistical significance was given to cardiovascular disease adjusted for hypertension, dementia and medication use for osteo-articular diseases and gastric protectors. Osteoarthritis, especially of proprioceptive origin, or relating to disorders in the cervical column, or imbalance caused by decreased joint strength, was also cited as a factor in the emergence of dizziness.

Studies ${ }^{14,20,21}$ have found that the side effects of medications represent $23 \%$ of the causes of dizziness and that medication can trigger dizziness in $18.7 \%$ of cases. A higher number of substances taken results in a greater chance of a deleterious effect, due to the combination of medications involved. The use of more than four combined medications is related to the emergence of dizziness in elderly persons ${ }^{17,18}$, and it was found that use of five or more medications resulted in a 1.31 times greater risk of dizziness ${ }^{22}$, whether as a result of the side effects, or the interactions between the drugs. In this study, the use of gastric protectors actually made the use of many drugs, acting as a proxy variable. Thus, the association between dizziness and proton pump inhibitor drugs actually suggested an association between use of various drugs and dizziness.

\section{CONCLUSION}

The prevalence of dizziness is high among institutionalized elderly persons. A large number of illnesses, the presence of cardiovascular disease, 
arterial hypertension, osteoarthritis and the use of gastro-protective medication is associated with dizziness among this population.

\section{REFERENCES}

1. Pinto SPLC, Simson ORMV. Long-term care facilities for elderly in Brazil: summary of legislation. Rev Bras Geriatr Gerontol. 2012; 15(1):169-74.

2. Dias BB, Mota RS, Gênova TC, Tamborelli V, Pereira VV, Puccini PT. Aplicação da escala de equilíbrio de Berg para verificação do equilíbrio de idosos em diferentes fases do envelhecimento. Rev Bras de Ciên do Envelh Hum. 2009; 6(2):213-24.

3. Ganança MM, Caovilla HH. Desequilíbrio e reequilíbrio. In: Ganança MM. Vertigem tem cura? O que aprendemos nestes últimos 30 anos. 1998. Lemos Editorial, São Paulo, pp 13-9.

4. Lo AX, Harada CN. Geriatric dizziness. Evolving diagnostic and therapeutic approaches for the emergency department. Clin Geriatr Med. 2013; 29(1):181-204.

5. Alrwaily M, Whitney SL. Vestibular rehabilitation of older adults with dizziness. Otolaryngol Clin North Am. 2011; 44(2):473-96.

6. Liston MB, Bamiou DE, Martin F, et al. Peripheral vestibular dysfunction is prevalent in older adults experiencing multiple non-syncopal falls versus age-matched non-fallers: a pilot study. Age Ageing. 2013; 0:1-6.

7. Ferreira LMBM, Figueiredo-Ribeiro KMOB, Pestana ALS, Lima KC. Prevalence of dizziness in older people. Rev CEFAC. 2014; 16(3):73946.

8. Moraes SA, Soares WJS, Rodrigues RAS, Fett WCR, Ferriolli E, Perracini MR. Dizziness in community-dewelling older adults: a population-based study. Braz J Otorhinolaryngol. 2011; 77(6):691-9.

9. Barin K, Dodson EE. Dizziness in the elderly. Otolaryngol Clin North Am. 2011; 44(2):437-54.

10.Simoceli L, Bittar RMS, Bottino MA, Bento RF. Diagnostic approach of balance in the elederly: preliminary results. Braz $\mathrm{J}$ Otorhinolaryngol. 2003; 69(6):772-7.

11. Fabrício SCC, Rodrigues RAP, Costa Júnior ML. Accidental falls in institucionalized elderly people. Acta Paul Enferm. 2002; 15(3):51-9.

12. Lee R, Elder A. Dizziness in older adults. Medicine. 2013; 41(1):16-9.

13. Bittar RMS, Simoceli L, Pedalini MEB, Bottino MA. The treatment of diseases related to balance disorders in the elderly and the effectiveness of vestibular rehabilitaton. Braz J Otorhinolaryngol. 2007; 73(3):295-8.

14. Maarsingh OR, Dros J, Schellevis FG, et al. Causes of Persistent Dizziness in Elderly Patients in Primary Care. Ann Fam Med. 2010; 8(3):196-205. 
15. Dros J, Maarsingh OR, van der Horst HE, Bindels PJ, Ter Riet G, van Weert HC. Tests used to evaluate dizziness in primary care. Can Med Assoc J. 2010; 182(13):621-31.

16. Canavan PK, Cahalin LP, Lowe S, Fitzpatrick D, Harris M, PlummerD'Amato $P$. Managing gait disorders in older persons residing in nursins homes: a review of literature. J Am Med Dir Assoc. 2009; 10(4):230-7.

17. Gomez F, Curcio CL, Duque G. Dizziness as a geriatric condition among rural community-dwelling older adults. J Nutr Health Aging. 2011; 15(6):490-7.

18.Gassmann KG, Rupprecht R. Dizziness in an older community dwelling population: a multifactorial syndrome. J Nutr Health Aging. 2009; 13(3):278-82.

19. Stevens KN, Lang IA, Guralnik JM, Melzer D. Epidemiology of balance and dizziness in a national population: findings from the English Longitudinal Study of Ageing. Age Ageing. 2008; 37:300-5.

20. Lin HW, Bhattacharyya N. Balance disorders in the elderly: epidemiology and functional impact. Laryngoscope. 2012; 122(8):1858-61.

21. Cassoni TCJ, Corona LP, Romano-Lieber NS, Secoli SR, Duarte YAO, Lebrão L. Uso de medicamentos potencialmente inapropriados por idosos do Município de São Paulo, Brasil: Estudo SABE.Cad. Saúde Pública, 2014. 30(8):1708-20

22. Tamber A, Bruusgaard D. Self-reported faintness or dizziness comorbity and use of medicines. An epidemiological study. Scand $\mathrm{J}$ Public Health. 2009; 37:613-20. 